\title{
DETERMINANTS OF ENSURING OF THE AGRO-INDUSTRIAL ENTERPRISES' ECONOMIC SECURITY
}

\author{
Shashlo N.V., Candidate of Economic Sciences \\ Vladivostok State University of Economics and Service, Vladivostok, Russia \\ E-mail: ninelllsss@gmail.com
}

\begin{abstract}
The article explores theoretical approaches to determining the essence of the category of economic security of an enterprise. Approaches to the definition of the essence of economic security - strategic, resource-functional, market, competitive, harmonized, protective, deductive, systemic and criminal. The system of economic security of the enterprise is considered as part of the management system aimed at countering external and internal threats to the functioning of the enterprise. A comprehensive approach was developed, within which the structure of the enterprise's economic security system was formed. The components of the economic security system are the subjects of the system, resources, the organizational and legal basis for the construction and functioning of the economic security system, the mechanisms for managing the system, the mechanisms for strategic interaction, technologies, methods and means for ensuring economic security. In order to assess threats and counteract them, it is suggested to conduct diagnostics with the definition of the aggregate criterion of the impact of a threat on the economic security of an enterprise.
\end{abstract}

\section{KEY WORDS}

Enterprise, economic security, resources, risk, threat, strategy, counteraction, danger.

The economic security of enterprise has an important meaning since it is characteristic of the enterprise ability to effective activity, development, economic stability and competitiveness. As a result, the goal of the research is working out an integrated approach to provide enterprises with economic security and tools to achieve it.

While researching evolution of theoretical approaches to an entity of the enterprise economic security, it is revealed that security was considered as ensuring the conditions of storage of a trade secret in papers of the 90th $[3,8,9]$. There's also another approach interpreting economic security as the condition of the enterprise which provides its ability to resist influencing of adverse factors. A significant number of interpretations of this category testifies that justification of the theoretical and methodical process is unaccomplished. Based on this, we have identified approaches to the definition of the essence of economic security.

Proceeding from it we have singled out approaches to determination of entity of an economic security, which are strategic - a condition of the enterprise security from internal and external threats [5]; resource and functional - an effective usage of resources or potential and allocation of its functional components; market - an effective usage of resources to provide market development of the enterprise [7]; competitive - a presence of the competitive advantages [6]; harmonized - an achievement of proportionality and coordination of the characteristics system elements; protective - a protection of the enterprise economic interests; deductive - a condition of the enterprises free from disturbance; system - an ensuring of safety, balance and stability of the enterprise; penal - a protection from economic crimes.

Having analyzed approaches we can note that most of them reflect several directions: the first one - "protective" - is based on usage of the concept if threat, the second - "resource and functional" - is an effective usage of resources and potential, the third - "profitable" - is a getting a profit. The most used directions are protective and resource and functional. This usage is caused by understanding of an economic security as a condition of being protected from threats, and understanding of resource ensuring as a condition of functioning and a base for ensuring of economic security. 
Consequently, economic security is a condition of enterprise developing, which guarantees and provides the most effective usage and development of resources of all types and components of potential that promotes stability of economic and financial development, effectiveness of neutralization, prevention and counteraction to internal and external factors with the purpose of achievement of a strategic mission.

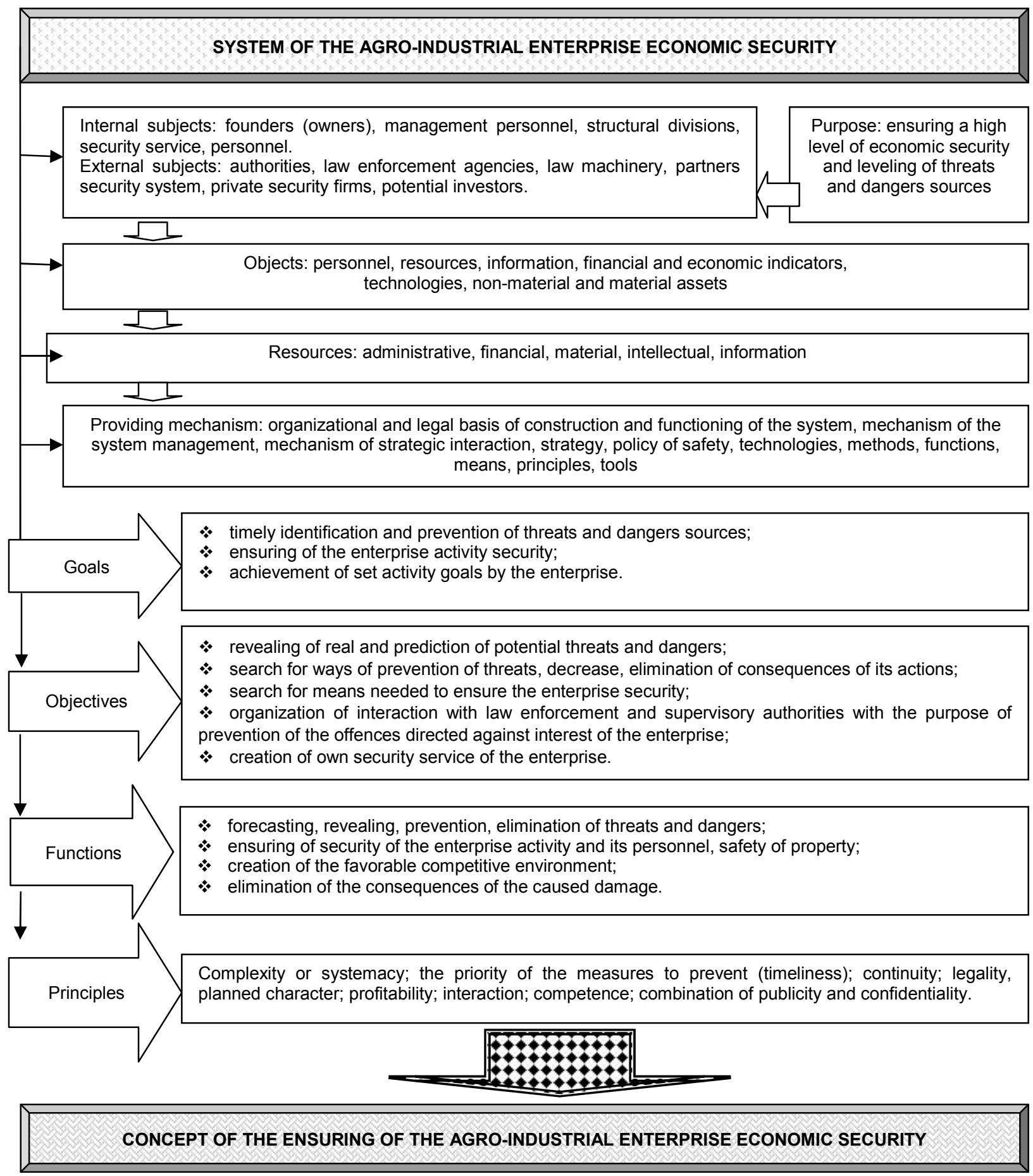

Figure 1 - System of the agro-industrial enterprise economic security

In the era of an informational economy the ensuring of economic security of the enterprise is needed by means of management that demands creation of own security system to revelation and prevention of threats, ensuring achievement of the goals of activity $[1,2,8]$. The system approach is based on the principle of integrity of an object that is a 
research of the economic security properties as whole [4]. Existence of such properties is caused by result of emergence a synergetic connection between elements. This connection provides an effect which is bigger than the sum of the effects of the elements functioning independently of each other. Creation of the system is carried out due to structure of correlations between components. Therefore the system of economic security is considered as a part of the management system, directed to counteraction to external and internal threats to the enterprise functioning (fig. 1).

Structural components of economic security system are subjects of the system, resources, legal and institutional framework of organization and functioning of the economic security system, mechanisms of system management, and mechanisms of strategic interaction, technologies, methods and means of ensuring of economic security.

The system of the economic security includes an internal component (core), external component (outline of economic security). The internal component is ability of the enterprise to organize its internal structure and internal relations so it could as much as possible ensure its own economic security. The internal components are financial; production and technological; rational land use; intellectual and personnel; marketing; power. The external component reflects ability to organize external interaction so it could ensure protection against threats, fulfill possibilities of the security level increase. The external components are interfacing; innovative and technological; institutional and legal; raw and power; ecological.

The enterprise economic security system must constantly expect for threat signals from external and internal environment and response adequately to them. Thus the enterprise economic security system can be considered as organized set of interconnected elements of the external and internal enterprise security, integration of the functional subsystems aimed at providing of the achievement of the enterprise interests, as well as providing of the enterprise functioning in conditions of unstable external and internal environment. The economic security system is designed according to the developed policy and strategy of security ensuring. With the purpose of the analysis of threats and their counteraction [10] it is expedient to carry out diagnostics that includes an estimation order, qualitative and quantitative criteria of estimation of probability of threat approach and size of the destabilizing influence (loss), qualitative and quantitative criteria for the cumulative expected criterion of the threat influence on economic security (f.1):

$$
I=\frac{K_{e 1}\left(P_{1} \times D_{1}\right)+K_{e 2}\left(P_{2} \times D_{2}\right)+\cdots+K_{e n}\left(P_{n} \times D_{n}\right)}{G}
$$

I - the cumulative expected criterion of the threat influence on economic security, with a scale: $0,01-0,20$ - insignificant threat; $0,21-0,50$ - moderate threat; 0,51-0,80 - significant threat; $0,81-0,1$ - dangerous threat; $K_{\mathrm{ei}}$ - weight coefficient of the expert opinion from 1 to 0 , sum of all weight coefficient $=1$.

$$
\sum_{i=1}^{n} K \mathrm{ei}=1
$$

$P_{i}$ - probability of threat approach: $0,1-0,15$ - improbable threat, 0,16-0,99-potential threat, 1 - real threat; $D_{i}$ - possible destabilization influence: 1 - minor damage, 2 - moderate damage, 3 - significant damage, 4 - destructive damage; $G$ - number of experts.

Calculating of integrated quality and quantity index of security and its comparison with planned and standard allows forming a conclusion about efficiency of realization of the developed economic security system. The creation of the enterprise economic security system is a process of strategic management that considers threats and risks and develops mechanisms of counteraction. Thus the enterprise economic security is defined by condition of security if the systems at implementation economic activity; by a condition of resources and enterprises abilities; by a set of methods with organizational and legal, regime and security, technical, technological, economic, financial and information and analytical character; by a condition of social and technological system that allows avoiding threats and resisting to disorganization factors by means of the structural organization management connections. The purpose of economic security is guaranteeing stable and the most effective 
functioning, economic growth, exclusion of opportunities of receiving losses, their prevention and counteraction to their influence.

\section{REFERENCES}

1. Dmitrieva L.N., Duvanova Yu.N., Ekonomika. Innovatsii. Upravlenie kachestvom, 2013, №3(4), 125-126. (in Russian)

2. Feofilova T.Yu., Bol'shakov S.N. Teoriya i metodologiya ekonomicheskoi bezopasnosti v regional'nom kontekste. Syktyvkar: KRAGSiU, 2014. (in Russian)

3. Gaponenko V.F., Bespal'ko A.L., Vlaskov A.S. Ekonomicheskaya bezopasnost' predpriyatii. Podkhody i printsipy. Izdatel'stvo «Os'-89», 2007. (in Russian)

4. Karanina E.V., Zagarskikh V.V. Ekonomicheskaya bezopasnost' gosudarstva, regiona i predpriyatiya: formirovanie i obespechenie s uchetom faktorov riskov. Kirov: VyatGU. 2016. (in Russian)

5. Kozachenko G.V. Systema ekonomichnoi' bezpeky: derzhava, region, pidpryjemstvo. Lugans'k: TOV «Virtual'na real'nist'», 2012. Vol.2, p. 318. (in Russian)

6. Krotov M. I., Muntiyan V.I. Ekonomicheskaya bezopasnost' Rossii: Sistemnyi podkhod. St-Petersburg: NPK «ROST», 2016. (in Russian)

7. Kuzubov A.A., Shashlo N.V., Vil'deman A.I. Azimut nauchnykh issledovanii: ekonomika i upravlenie, 2017, Vol. 6, №1 (18), 209-212. (in Russian)

8. Tkachenko V.I. Lugansk-Roven'ki: «Nauka», 2007. (in Russian)

9. Tkachenko V.G., Bogachov V.I., Shashlo N.V. Sushchnost', rol' i znachenie sel'skikh domokhozyaistv $\mathrm{v}$ obespechenii prodovol'stvennoi bezopasnosti Ukrainy. Kiev: Izdatel'skii dom «Vinichenko», 2013. (in Russian)

10. Vorotynskaya A.M. Izvestiya Sankt-Peterburgskogo universiteta ekonomiki i finansov, 2013, №2 (80), 98-100. (in Russian) 